\title{
BUILDERS OF THE FUTURE
}

\section{A MODEL FOR DEVELOPING THE CREATIVE ABILITIES OF PRESCHOOL CHILDREN BASED ON A PERSON-CENTERED APPROACH}

\author{
Mohira Juraqulovna Turdiyeva \\ Lecturer, \\ Department Of Preschool Education, \\ Bukhara State University Uzbekistan \\ Mohira.Turdiyeva@Bk.Ru \\ Mukhayyo Isroil Qizi Islomova \\ Student \\ Bukhara State University Uzbekistan. \\ DOI - https://doi.org/10.37547/builders-02
}

\begin{abstract}
In this article, the development of creative abilities of children of preschool age person-oriented individual opinion about the role of technology in education. Here are some important principles for developing a person-centered approach.

Keywords: preschool education, knowledge, skills, abilities, person-centered learning technology, individual education, principle, intellectual, communicative, artistic, physical, abilities, freedom, law.
\end{abstract}

\section{Introduction}

In today's world, children, no matter where they live, must go through a difficult life in a fast-paced world. The world is changing rapidly and rapidly, living and working conditions are changing, and new professions and technologies are emerging as a result of scientific and technical inventions. In today's world, people are constantly changing, learning new things throughout their lives. We need to start at an early age to prepare children for these drastic changes, to enrich them with the knowledge and experience they need for life.

A person-centered approach is to create a learning environment in which children's real personal interests and needs are met and children's personal experiences and knowledge are effectively accumulated. 


\section{BUILDERS OF THE FUTURE}

A person-centered approach is to focus the educator's attention on the child's personality, not only on developing his or her intellectual abilities and sense of civic responsibility, but also on developing a mental person with emotional, aesthetic, creative inclinations and developmental opportunities.

Person-centered education is one of the theoretical priorities of the concept of preschool education. The purpose of a conscious approach to the individual is to develop, not to "change" him under a given standard and pressure, but to create the conditions for him to be accepted as he is.

In principle, it is manifested not as a means of pedagogical activity, but as a means of its personal implementation.

This aspect is that the educator gives the pupil the right to choose freely according to his or her will, without giving up domination over the child, controlling him or her, using violence.

As educators, we must give every child the right to choose their own path of development based on their characteristics, values and aspirations.

Educators should develop a person-centered approach based on the following principles: The principle of self-expression. Every

child needs to show his or her intellectual, communicative, artistic and physical abilities. It is important to encourage and support the child's desire to show and develop his or her natural and social abilities.

The principle of individuality. The main task of the educational organization is to create conditions for the individual formation of the child's personality. It is necessary to take into account not only the individual characteristics of the child, but also to make a comprehensive contribution to his further development.

The principle of subjectivity. Individuality is unique to those who have subjective powers and skillfully use them to build activities, relationships, and relationships. It is important to help the child become a real subject in group life, to form and enrich his personal experience.

The principle of selection. Without choice, it is impossible to develop the individual characteristics and subjectivity of the child, to show his abilities. It is pedagogically 


\section{BUILDERS OF THE FUTURE}

acceptable for a child to live and be brought up in an environment where he or she has constant subjective authority to choose, to choose the purpose, content, forms and methods of organizing the educational process. This requires an open development environment (development centers) in preschool age groups.

The principle of activity, creativity and success. Success to the child should be encouraged. It is the introduction of play activities to encourage the child's active life position. It is very important for a child to be as creative as possible in his play and productive activity, and to have experience in his own creative activity. Individual and collective creative activity allows the identification and development of individual characteristics of the child.

The principle of trust and support. It is important to enrich pedagogical activity with humanities, person-centered teaching and learning technologies. The child needs to be supported by self-confidence, self-awareness and aspirations for self-realization, not to be overly demanding or overly controlled. It is not external influences but internal motivation that determine the success of a child's education and upbringing.

The principle of a different approach. Improving the personality of students solves the tasks of effective pedagogical support in the struggle, helps to create special pedagogical situations that help to reveal the psychophysical, personal abilities and capabilities of students. It is the development of a child according to his nature, health, mental and physical structure, abilities and tendencies, and perception.

It is possible to ensure that each child masters the program materials in the process of educational activities and in everyday life, provided that they are approached individually. It is very important to determine the child's attitude to the learning process and the level of his activity at work. Active children need to develop interest in activities, initiative, their abilities.

Given the level of development of children, it is necessary to give them additional tasks, to formulate more complex questions. Distracted, quick-tempered, hurried children can be asked to repeat the teacher's instructions and to concentrate before explaining, and to communicate with them in person. For example: "Bahromjon, Nurislam, children, listen carefully, then repeat what I said." This is a very simple and effective method, as it 


\section{BUILDERS OF THE FUTURE}

helps to draw children's attention to the teacher's instructions. Therefore, while helping children to remember the task, it also prevents them from responding hastily and thoughtlessly, and helps children to master the task and instructions better.

In short, individual work can be done in a small group of children or with a separate child. In order to maintain interest in children's creative work, individual work is carried out not only with children who have not mastered it, but also with others.

\section{Conclusion}

In addition, individual work has not only educational, developmental, but also educational value when introducing children to certain norms, rules, and so on. We can conclude that a well-organized individual work allows children to fully master the material of the program and has a great positive effect on their behavior.

\section{References:}

1. Turdieva M. J., Olimov K. T. Game Technologies As An Innovative Type Of StudentCentered Education //The American Journal of Social Science and Education Innovations. 2021. - T. 3. - №. 02. - C. 183-187.

2. Олимов К., Турдиева М. Maktabgacha ta'lim va tarbiya jarayonini amalga oshirishda innovatsion yondashuv va “ilk qadam” davlat o'quv dasturi //Общество и инновации. 2021. - T. 2. - №. 2/S. - C. 419-423.

3. Juraqulovna, Turdiyeva Mohira. "TYPES OF PERSON-CENTERED TECHNOLOGY IN THE EDUCATIONAL PROCESS." E-Conference Globe. Vol. 3. No. 1. 2021.

4. Rasulova L. G. Formation Of Abilities And Skills In Measuring Activity In Preschoolers //The American Journal of Social Science and Education Innovations. - 2021. - T. 3. - №. 02. - C. 363-369.

5. Gaybullaevna R. L. Information technology in primary school //Academicia: An International Multidisciplinary Research Journal. - 2021. - T. 11. - №. 1. - C. 1498-1503.

6. Nizomiddinovna K. N. Compliment as one of the forms of Phatic Communication //Middle European Scientific Bulletin. - 2021. - T. 10. - №. 1.

7. Гафурова А. Х. Роль Детской Литературы В Развитии Детей Дошкольного Возраста //Academy. - 2020. - №. 12 (63). 


\section{BUILDERS OF THE FUTURE}

8. Temirovna O. L., Chorievna R. L. Methodology to organize independent work of students in mathematics lessons in primary school //ACADEMICIA: An International Multidisciplinary Research Journal. - 2020. - T. 10. - №. 10. - C. 387-393.

9. Рахмонова Г. Ш., Чоршамова А. Ф. К. Значимые стороны национальных игр в процессе воспитания дошкольников //Проблемы педагогики. - 2020. - №. 1 (46).

10. Mirzayeva, Shavkatovna Dilfuza. "Innovative approaches to Teaching and Upbringing in Pre-School Institutions." Middle European Scientific Bulletin 10.1 (2021). 